\title{
Environmental effectiveness and economic consequences of fragmented versus universal regimes: what can we learn from model studies?
}

\author{
ANDRIES HOF, MICHEL DEN ELZEN AND DETLEF VAN VUUREN
}

\begin{abstract}
4.1 Introduction
The thirteenth conference of the parties of the climate convention had launched a negotiation process to craft a new international climate change agreement by the end of 2009. This agreement would need to stipulate emission reduction commitments, specify essential actions to adapt to the impacts of climate change and mobilize the necessary funding and technological innovation. Given these enormous challenges, the structure and design of a future climate agreement are still unclear. Besides the negotiations within the UN climate regime, major greenhouse gas emitting countries are also leading ad hoc debates in other forums, for example in the context of the Group of Eight and the Asia-Pacific Partnership on Clean Development and Climate. Depending on the course of these processes, a new climate governance regime could develop in different directions; it could end somewhere between a universal, inclusive governance architecture and a strongly fragmented, heterogeneous governance architecture (Biermann et al., this volume, Chapter 2).

In recent years, numerous universal and fragmented climate regimes have been proposed (for an overview, see Bodansky 2004; Blok et al. 2005; Philibert 2005; IPCC 2007: 770-773). Many of these regimes are quantitatively or qualitatively assessed, but no attempt has yet been made to compare the costs estimates of these studies for specific regions under different regimes. Nevertheless, the available material allows us to make an assessment of the regional costs of several universal and fragmented regimes, based on different models. This chapter presents a literature review concerning the economic effectiveness of a number of possible universal and fragmented regimes. We use only studies that quantitatively assess both emission reductions and costs. From a quantitative perspective, this chapter tries to answer the appraisal question of the 'architecture' domain of this book, namely whether a universal or a fragmented regime will be more effective to reduce greenhouse gas emissions.
\end{abstract}


The chapter is structured as follows. Section 4.2 describes the methodology, including the criteria used for inclusion of the assessment, a typology of regimes, how we compared the studies and how we dealt with emissions trading (see Flachsland et al., this volume, Chapter 5, for a detailed analysis on emissions trading). Section 4.3 analyses the universal and fragmented regimes based on our criteria. Finally, Section 4.4 concludes and briefly maps the policy options discussed.

\subsection{Methodology}

\subsubsection{Criteria for inclusion in the assessment}

While there are many criteria to evaluate climate regimes (den Elzen et al. 2003: 186; Höhne et al. 2003: 33-34; Bell et al. 2005: 33), the most important ones according to the IPCC are: environmental effectiveness, cost effectiveness, distributional effects and institutional feasibility (IPCC 2007: 751). Our focus is on the first three criteria, in order to bring our criteria in line with those of Flachsland et al. (this volume, Chapter 5). Environmental effectiveness relates to the reduction in greenhouse gas emissions that can be achieved by a regime. Other environmental effects, such as air quality, could also be included, but we focus only on greenhouse gas emissions. We address the economic consequences of climate regimes in terms of their cost effectiveness and distributional effects. Cost effectiveness relates to the extent to which the policy can achieve its objectives at a minimum cost to society (also see Section 4.2.5), while distributional effects relate to the distributional consequences of a policy, which includes dimensions such as equity or fairness (IPCC 2007: 751). These aspects are important because the probability of achieving an agreement will be reduced if the cost effectiveness is low or if the distributional effects - the differences in abatement costs between individual countries or groups of countries - are high.

So far, more than 50 climate regimes with different goals and/or actions have been proposed in the literature (IPCC 2007: 770-773). Our review includes only those studies that quantitatively assess regimes in terms of emission reductions and regional costs and which focus on the post-2012 period. The only exception is the assessment of a carbon tax, for which we use two different models. Direct abatement costs are projected using the Integrated Model to Assess the Global Environment (IMAGE 2.3) framework, which includes the energy model Targets Image Energy Regional (TIMER) 2.0 coupled to the Framework to Assess International Regimes for differentiation of commitments (FAIR) (van Vuuren et al. 2007). GDP losses are estimated by linking the IMAGE 2.3 model with the ENV-Linkages model (Bakkes and Bosch 2008). IMAGE is a dynamic integrated assessment modelling framework for global change, aimed at supporting decision-making by quantifying the relative importance of major processes and interactions in the society-biosphere-climate system.

\footnotetext{
${ }^{1}$ For more information, see www.mnp.nl/image.
} 
ENV-Linkages is a global macroeconomic general equilibrium model containing 26 sectors and 34 world regions and provides economic projections for multiple time periods.

\subsubsection{Typology of regimes}

The fundamental difference between a universal and fragmented regime is that the former involves a single comprehensive climate regime that applies to all countries (Biermann et al., this volume, Chapter 2). This means that universal climate regimes require full participation of all countries, at least gradually, in the same international agreement, whereas fragmented climate regimes never achieve full participation in a single international agreement.

Figure 4.1 classifies the assessed regimes according to the number of participating countries. Regimes with more than one agreement or without full (gradual) participation are fragmented regimes. Since for our modelling analysis we have to rely on quantifiable criteria, our distinction of fragmented and universal regimes is not completely congruent with the distinction introduced by Biermann et al. (this volume, Chapter 2). These authors also refer to participation in terms of 'actor constellation', but in addition, they rely on qualitative criteria, namely 'institutional overlaps' and 'norm conflicts'. We, however, focus on the quantifiable criteria of participation and number of agreements. We regard a regime as more universal when more countries participate and when there are fewer different agreements involved. Therefore, it is possible to have a fragmented regime in which all countries contribute in some way to reduce emissions, although using different agreements. An example would be a regime in which the United States, Australia, India, China, Japan and South Korea continue to focus on cooperation on development and transfer of technology within the Asia-Pacific Partnership on Clean Development and Climate, while the rest of the world uses a system of absolute emission targets with the possibility of emission trading (Biermann et al., this volume, Chapter 2). Universal regimes can have a higher or lower degree of participation as well. Regimes in which all countries participate immediately, based on one common rule, are perfectly universal. An example would be 'contraction and convergence', in which all countries participate according to the rule of converging per capita emissions. A number of universal regimes, however, have a gradual participation approach or staged system approach. In the latter approach, countries participate in a system with stages and stage-specific targets, where the transition between stages is a function of various indicators, such as per capita income thresholds (Gupta 1998; Berk and den Elzen 2001; Höhne et al. 2003). Another crucial factor that qualifies regimes is the type of target, where two broad distinctions can be made: 


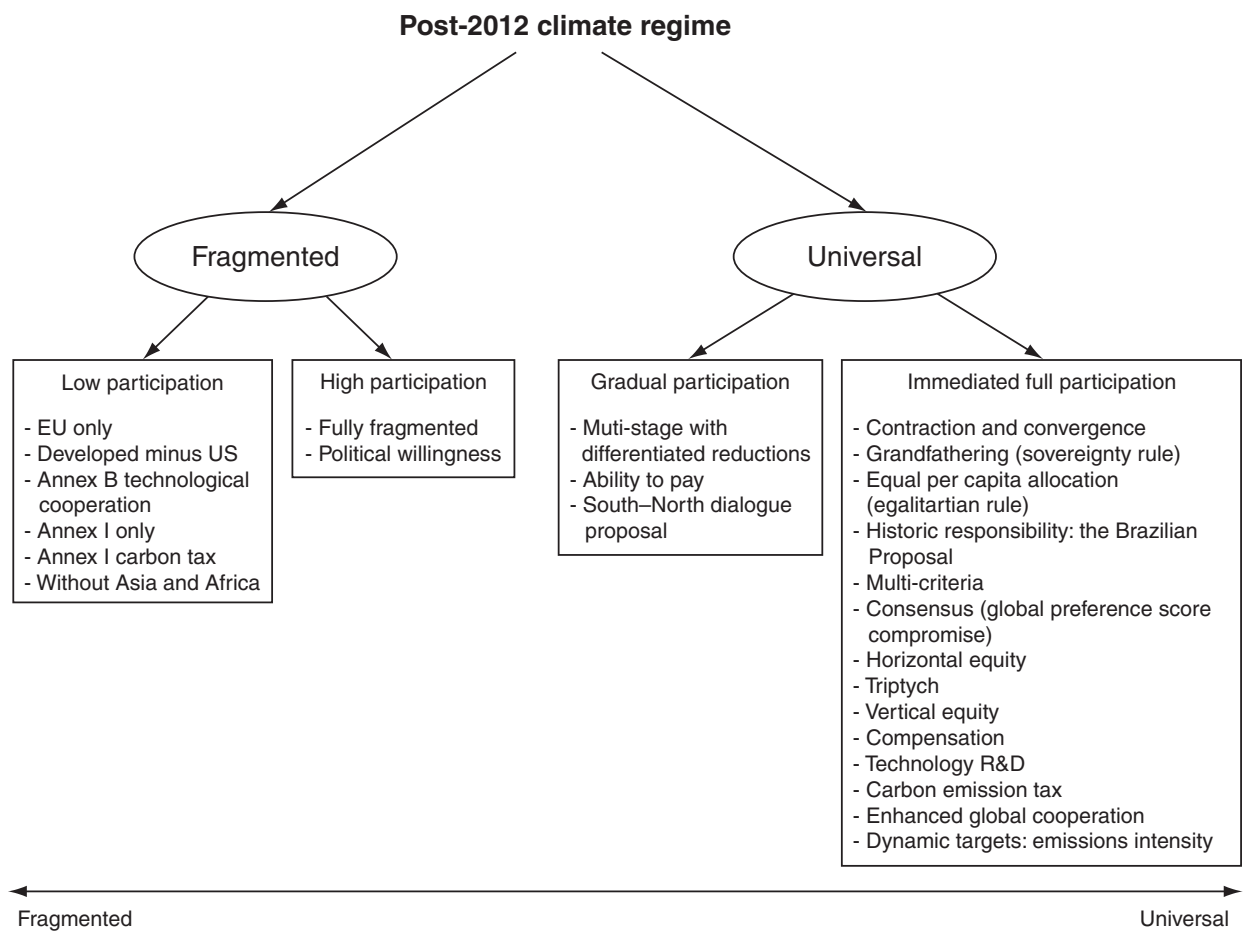

Figure 4.1 Quantitatively assessed post-2012 fragmented and universal climate regimes. Tables 4.1, 4.2 and 4.7 explain the different climate regimes mentioned in Figure 4.1.

(1) Regimes with predefined emission targets These regimes specify targets in terms of emission reductions. Often these emission targets are derived from a certain climate target, like the concentration stabilization level. Most universal regimes are of this type.

(2) Regimes without predefined emission targets These regimes do not include emission targets, but instead technological cooperation or a carbon emission tax, for instance. Fragmented and universal regimes can both be of this type.

Because these two types of regimes are difficult to compare, we analyse them separately.

\subsubsection{Comparing quantitative assessments focusing on costs and reductions}

Comparing studies that assess various climate regimes is not always a straightforward task. Studies use different assumptions and report different cost measurements. General equilibrium models usually measure costs in GDP or welfare loss, whereas in partial equilibrium models (energy system models) costs are measured in direct abatement costs. These two cost measurements are in absolute values not directly comparable. Therefore, we focus on the relative costs of different regions 
using both metrics, while Flachsland et al. (this volume, Chapter 5) consider direct abatement costs only.

For most regimes, the actual design ('regime parameters') is crucial for the outcome. Such regime parameters can include the overall concentration target (for example 450, 550 or 650 ppm carbon dioxide-equivalent), the baseline (high or low), discount rate (level and type) and marginal abatement costs. Other assumptions are regime-specific. For example, for the 'contraction and convergence' regime the convergence year can strongly determine the outcomes. Our analysis states for every assessment the major parameter settings, the cost measurement and the details of the regime.

\subsubsection{Emission trading}

Almost all regimes can be constructed so that emission trading is either allowed or not allowed. Many studies analyse the effect of emission trading or the clean development mechanism on the costs of emission abatement; all studies conclude that emission trading and the clean development mechanism decreases the cost of abatement (see, for example, Leimbach 2003: 1041; Böhringer and Welsch 2004: 32; Bollen et al. 2005: 16; Russ et al. 2005: 21; European Commission 2007: 48). This holds for all universal regimes (both full and gradual participation) and to a lesser extent for the fragmented climate regimes (depending on the size of coalitions). Emission trading not only reduces the overall costs of the regime, but also decreases the costs for every country participating in the coalition. To effectively compare the economic consequences of various climate regimes, we restrict our study to regimes that assume full emission trading between countries participating in the same coalition. However, in the case of fragmented regimes, none of the studies we consider assumes the possibility of trade between countries belonging to different coalitions. Flachsland et al. (this volume, Chapter 5) provide such an analysis of the environmental and cost effectiveness of fragmented carbon markets as compared to more integrated approaches for emission trading.

\subsection{Analysis}

\subsubsection{Universal regimes}

The majority of climate regime proposals presume global international climate negotiations with the goal of a single, comprehensive regime (IPCC 2007: 770-773). Most regimes predefine a global emission target and then apply allocation rules specifying the allocation of global emission reductions to countries or regions. In universal regime proposals, the global emission target can be set at any preferred level. In most cases, the authors looked at global short-term emission targets that are compatible with meeting long-term concentration stabilization targets in the range of 
Table 4.1 Universal regimes with a global emission target

\begin{tabular}{ll}
\hline \hline Name & Short description \\
\hline $\begin{array}{l}\text { Full participation regimes } \\
\begin{array}{l}\text { Contraction and } \\
\text { convergence }\end{array}\end{array}$ & $\begin{array}{l}\text { Distribute permits so } \\
\text { per capita emissions } \\
\text { converge in a certain } \\
\text { year }\end{array}$
\end{tabular}

Grandfathering (sovereignty rule)
Distribute permits in proportion to current emissions
Equal per capita allocation (egalitarian rule)
Distribute permits in proportion to population
Historic responsibility - the Brazilian Proposal

Multi-criteria
Consensus (global preference score compromise)
Horizontal equity

Vertical equity proportion to the contribution of climate change over a certain period

Distribute permits based on a formula including several variables, such as population, GDP and others

A combination of per capita allocation and grandfathering

Distribute permits to equalize net welfare change as per cent of GDP

Progressively distribute
Evaluated in terms of emission reductions and costs by

Blanchard (2002), Böhringer and Helm (2008), Böhringer and Welsch (2004; 2006), Bollen et al. (2004, 2005), Criqui et al. (2003), den Elzen and Lucas (2005), den Elzen et al. (2005, 2008), Leimbach (2003), Manne and Richels (1995), Manne et al. (1995), Nakicenovic and Riahi (2003), Persson et al. (2006), Peterson and Klepper (2007)

Böhringer and Welsch (2006), Böhringer and Löschel (2005), Bollen et al. (2005), Buchner and Carraro (2003), den Elzen and Lucas (2005), Peterson and Klepper (2007), Rose et al. (1998)

Böhringer and Helm (2008), Böhringer and Welsch (2006), den Elzen and Lucas (2005), Persson et al. (2006), Rose et al. (1998), Wicke and Böhringer (2005)

Blanchard (2002), den Elzen and Lucas (2005), den Elzen et al. (2005), Rive et al. (2006) permits proportions inversely correlated with per capita GDP den Elzen and Lucas (2005), Vaillancourt and Waaub (2006)

den Elzen and Lucas (2005), Rose et al. (1998)

Rose et al. (1998), Vaillancourt et al. (2008)

Rose et al. (1998), Vaillancourt et al. (2008) 
Table 4.1 (cont.)

\begin{tabular}{|c|c|c|}
\hline Name & Short description & $\begin{array}{l}\text { Evaluated in terms of emission } \\
\text { reductions and costs by }\end{array}$ \\
\hline Triptych & $\begin{array}{l}\text { National emission } \\
\text { targets based on } \\
\text { sectoral } \\
\text { considerations }\end{array}$ & den Elzen and Lucas (2005) \\
\hline \multicolumn{3}{|c|}{ Gradual participation regimes } \\
\hline $\begin{array}{l}\text { Multi-stage with } \\
\text { differentiated } \\
\text { reductions }\end{array}$ & $\begin{array}{l}\text { Countries participate } \\
\text { with different stages } \\
\text { and stage-specific } \\
\text { types of targets; } \\
\text { countries transition } \\
\text { between stages as a } \\
\text { function of indicators }\end{array}$ & $\begin{array}{l}\text { Boeters et al. (2007), Criqui et al. } \\
\text { (2003), den Elzen and Lucas } \\
\text { (2005), den Elzen } \text { et al. }(2005 \\
\text { 2008) }\end{array}$ \\
\hline Ability to pay & $\begin{array}{l}\text { Permits are distributed } \\
\text { in order to equalize } \\
\text { abatement costs as } \\
\text { per cent of GDP }\end{array}$ & $\begin{array}{l}\text { Böhringer and Löschel (2005), den } \\
\text { Elzen and Lucas (2005) }\end{array}$ \\
\hline $\begin{array}{l}\text { South-North dialogue } \\
\text { proposal }\end{array}$ & $\begin{array}{l}\text { Countries participate in } \\
\text { the system with } \\
\text { different stages and } \\
\text { stage-specific types } \\
\text { of targets }\end{array}$ & den Elzen et al. (2007a) \\
\hline
\end{tabular}

$450-650 \mathrm{ppm}$ carbon dioxide-equivalent. A relatively strong point of all universal regimes with predefined targets is that environmental effectiveness is secured. However, in reality this effectiveness is obviously a function of compliance.

Tables 4.1 and 4.2 show allocation proposals with and without predefined global emission targets that have been quantitatively assessed regarding their economic consequences for the post-2012 period. (On studies that evaluated proposals solely in terms of emission reduction targets but not in terms of costs see Höhne et al. 2003 and Blok et al. 2005.)

\section{Universal regimes with a predefined emission target}

\section{'Contraction and convergence'}

Of all regimes, the 'contraction and convergence' regime has been analysed most often. The most crucial reason is its simple formulation - which makes it a good reference for any form of allocation. The first step in the 'contraction and convergence' regime is to establish a long-term global emission profile. Then emission rights are allocated so that the per capita emissions converge from their current 
Table 4.2 Economic consequences of universal regimes without a global emission target

\begin{tabular}{|c|c|c|}
\hline Name & Short description & Evaluated in terms of costs by \\
\hline Carbon emission tax & $\begin{array}{l}\text { All countries agree to a common, } \\
\text { international greenhouse gas } \\
\text { emission tax }\end{array}$ & $\begin{array}{l}\text { Bollen et al. (2005), Manne } \\
\text { et al. (1995), Peterson } \\
\text { and Klepper (2007), } \\
\text { Vaillancourt et al. (2008) }\end{array}$ \\
\hline $\begin{array}{l}\text { Dynamic targets: } \\
\text { emissions intensity }\end{array}$ & $\begin{array}{l}\text { Targets are defined as a certain } \\
\text { reduction of the ratio of carbon } \\
\text { dioxide emissions to GDP }\end{array}$ & Blanchard (2002) \\
\hline $\begin{array}{l}\text { Technology research } \\
\text { and development }\end{array}$ & $\begin{array}{l}\text { A regime based on enhanced } \\
\text { coordinated technology } \\
\text { research and development }\end{array}$ & Buchner and Carraro (2004) \\
\hline $\begin{array}{l}\text { Enhanced global } \\
\text { cooperation }\end{array}$ & $\begin{array}{l}\text { Joint welfare maximization with } \\
\text { an additional } 10 \text { per cent } \\
\text { emission reduction }\end{array}$ & Buchner and Carraro (2003) \\
\hline
\end{tabular}

values to a global average in a specific target year. Table 4.3 shows some of the chief parameters used in the various assessments of the 'contraction and convergence' regime.

Comparing the results from these studies is challenging due to the large variations in cost measurements, convergence year and targets. In order to decouple results from specific cost indicators and baseline or reduction targets, we analyse the costs of certain key regions relative to the global average costs as share of GDP. Table 4.4 shows the results. ${ }^{2}$ Every study finds substantial cost differences between regions. All studies, except Criqui et al. (2003), project high costs for the former Soviet Union and Eastern Europe due to (1) an unfavourable combination of high per capita emissions and low GDP and (2) reduced fossil fuel exports. For the same reasons, most studies also project high costs for the Middle East/North Africa. A few studies, however, expect net benefits for this region. Different projections of the abatement costs in this region are the major reason for these variations in cost projections. All studies agree that India and sub-Saharan Africa will profit from a 'contraction and convergence' regime with a 2050 convergence year, while they expect China to incur lower costs as compared to the global average. Most studies predict that the costs for Europe and the United States will be somewhat above the global average.

\footnotetext{
2 The studies of Nakicenovic and Riahi (2003), Manne and Richels (1995) and Manne et al. (1995) are not included in this table because they only reported results from a few highly aggregated regions.
} 
Table 4.3 Parameters of 'contraction and convergence' regime cost assessments

\begin{tabular}{|c|c|c|c|c|}
\hline Study & Regions & Cost measurement & Convergence year & Target \\
\hline Blanchard (2002) & 17 & Direct costs 2030 & 2050 & $9.4 \mathrm{GtC}$ in $2030^{a}$ \\
\hline $\begin{array}{l}\text { Böhringer and } \\
\text { Welsch (2004, } \\
\text { 2006), Böhringer } \\
\text { and Helm (2008) }\end{array}$ & 11 & $\mathrm{NPV}^{b}$ income & 2050 & $\begin{array}{l}25 \text { per cent below } \\
1990 \text { in } 2050^{c}\end{array}$ \\
\hline Bollen et al. (2004) & 6 & $\begin{array}{l}\text { GDP and income } \\
2040\end{array}$ & 2050 & $\mathrm{~S} 550 \mathrm{e}^{d}$ \\
\hline Bollen et al. (2005) & 13 & Income 2020 & 2024 & S550e \\
\hline Criqui et al. (2003) & 11 & $\begin{array}{l}\text { Welfare } 2025 \text {, } \\
\text { direct } 2025 / \\
2050\end{array}$ & 2050 and 2100 & S550e and S650e \\
\hline $\begin{array}{l}\text { den Elzen and Lucas } \\
\text { (2005) }\end{array}$ & 18 & $\begin{array}{l}\text { Direct costs } 2025 \\
\text { and } 2050\end{array}$ & 2050 & S550e and S650e \\
\hline $\begin{array}{l}\text { den Elzen et al. } \\
\text { (2005) }\end{array}$ & 11 & $\begin{array}{l}\text { Direct costs } 2025 \\
\text { and } 2050\end{array}$ & 2050 and 2100 & S550e \\
\hline den Elzen et al. & 10 & $\begin{array}{l}\text { Direct costs } 2020 \\
\quad \text { and } 2050\end{array}$ & 2050 & $\mathrm{~S} 450 \mathrm{e}$ and $\mathrm{S} 550 \mathrm{e}$ \\
\hline Leimbach (2003) & 11 & $\begin{array}{l}\text { Consumption loss } \\
1990-2045 \text { and } \\
2050-2100\end{array}$ & 2025 and 2100 & $2^{\circ} \mathrm{C}$ \\
\hline $\begin{array}{l}\text { Manne et al. (1995), } \\
\text { Manne and } \\
\text { Richels (1995) }\end{array}$ & 5 & NPV GDP & 2030 and 2200 & Several explored \\
\hline $\begin{array}{l}\text { Nakicenovic and } \\
\text { Riahi (2003) }\end{array}$ & 5 & $\begin{array}{l}\text { GDP 2020, } 2050 \\
\text { and } 2100\end{array}$ & 2050 and 2100 & $\mathrm{~S} 400 \mathrm{c}, \mathrm{S} 450 \mathrm{c}^{e}$ \\
\hline Persson et al. (2006) & 5 & NPV direct & 2050 & $\mathrm{~S} 450 \mathrm{c}$ \\
\hline $\begin{array}{l}\text { Peterson and } \\
\text { Klepper (2007) }\end{array}$ & 12 & Welfare 2030 & 2050 & S550e \\
\hline
\end{tabular}

${ }^{a}$ Consistent with a 450 to $550 \mathrm{ppm}$ carbon dioxide stabilization goal (Blanchard 2002).

${ }^{b}$ Net Present Value: lifetime change in costs discounted to present values.

${ }^{c}$ Corresponds to a concentration stabilization level of $550 \mathrm{ppm}$ carbon dioxide-equivalent.

${ }^{d}$ Stabilization greenhouse gas concentration level at $550 \mathrm{ppm}$ carbon dioxide-equivalent.

${ }^{e}$ Stabilization concentration level at 400 and $450 \mathrm{ppm}$ carbon dioxide, which corresponds to a greenhouse gas concentration level of 500 and $550 \mathrm{ppm}$ carbon dioxide-equivalent (den Elzen et al. 2003).

Criqui et al. (2003), den Elzen et al. (2005) and Leimbach (2003) look more closely at the effects of a convergence year of 2100 instead of 2050 or 2025 . All three studies conclude that delaying the convergence year reduces costs substantially for industrialized countries. On the other hand, convergence in 2100 leads to much higher costs for developing countries, especially for India and countries in Africa. 
Table 4.4 Regional costs compared to global average costs (1)

\begin{tabular}{|c|c|c|c|c|c|c|c|c|}
\hline Study & $\begin{array}{l}\text { USA/ North } \\
\text { America }\end{array}$ & $\begin{array}{l}\text { European Union/ } \\
\text { enlarged European } \\
\text { Union }\end{array}$ & $\begin{array}{l}\text { FSU/ } \\
\text { Russia }\end{array}$ & $\begin{array}{l}\text { Middle East/ } \\
\text { Middle East } \\
\text { and N Africa }\end{array}$ & $\begin{array}{l}\text { Latin/ } \\
\text { South } \\
\text { America }\end{array}$ & $\begin{array}{l}\text { Africa/ sub- } \\
\text { Saharan } \\
\text { Africa }\end{array}$ & $\begin{array}{l}\text { China/ East } \\
\text { Asia }\end{array}$ & $\begin{array}{l}\text { India/ } \\
\text { South Asia }\end{array}$ \\
\hline $\begin{array}{l}\text { den Elzen and Lucas (2005), den } \\
\text { Elzen et al. (2005) }{ }^{a}\end{array}$ & 2 & 2 & 3 & 3 & 2 & 0 & 1 & 0 \\
\hline den Elzen et al. $(2008)^{b}$ & 2 & 2 & 3 & 2 & 1 & 0 & 1 & 0 \\
\hline $\begin{array}{l}\text { Böhringer and Welsch }(2004,2006) \text {, } \\
\text { Böhringer and Helm }(2008)^{c}\end{array}$ & 3 & 2 & 3 & 0 & 0 & 0 & 1 & 0 \\
\hline Criqui et al. $(2003)^{d}$ & 1 & 1 & 0 & 3 & 1 & 0 & 0 & 0 \\
\hline Peterson and Klepper $(2007)^{e}$ & 1 & 1 & 3 & 3 & 2 & 0 & 0 & 0 \\
\hline Blanchard $(2002)^{f}$ & 3 & 2 & 3 & 3 & NA & 0 & 2 & 0 \\
\hline Leimbach $(2003)^{g}$ & 2 & 1 & 3 & 0 & NA & 0 & 1 & 0 \\
\hline Persson et al. $(2006)^{h}$ & NA & NA & NA & 0 & 0 & 0 & 1 & 0 \\
\hline Bollen et al. $(2005)^{i}$ & 2 & 2 & 3 & 3 & 3 & NA & NA & NA \\
\hline Bollen et al. (2004) & 2 & 2 & 3 & 3 & NA & NA & NA & NA \\
\hline
\end{tabular}

The table shows regional costs compared to global average costs for the 'contraction and convergence' regime with emission trading and convergence in 2050 (exceptions: Bollen et al. 2005 convergence in 2024; Leimbach 2003 convergence in 2025) for a greenhouse gas concentration stabilization target of $550 \mathrm{ppm}$ carbon dioxide-equivalent or 450 carbon dioxide ppm.

Legend: $0=$ no costs or gains, $1=$ costs less than global average, $2=$ costs between global average and twice the global average, $3=$ costs more than twice the global average; NA = not available.

${ }^{a}$ Direct costs in 2025 .

${ }^{b}$ Direct costs in 2050 .

${ }^{c}$ Net Present Value of change in income.

${ }^{d}$ Change in welfare in 2025 .

${ }^{e}$ Change in welfare in 2030.

${ }^{f}$ Direct costs in 2030 .

${ }^{g}$ Consumption loss in the period 1990-2045.

${ }^{h}$ Net Present Value of direct costs.

${ }^{i}$ Income in 2020. In this study there is one Rest of World region with large benefits, explaining the fact that all regions reported here incur higher costs than the global average.

${ }^{j}$ Income in 2040. In this study there is one Rest of World region with large benefits, explaining the fact that all regions reported here incur higher costs than the global average. 
Other emission allocation regimes.

Of the studies that analyse other universal emission allocation regimes, den Elzen and Lucas (2005) is the most comprehensive. In total, they analyse nine universal regimes with full and gradual participation with respect to regional abatement costs. This can be used to explore whether there are also large variations in the distribution of costs for other universal regimes. Table 4.5 summarizes their results.

All regimes analysed by den Elzen and Lucas are subject to substantial cost differences between regions. Interestingly, the Middle East, the former Soviet Union, Canada and Oceania incur high costs no matter what the regime. The regimes with the smallest cost differences between regions are Triptych, 'multistage' with differentiated reductions and the Brazilian proposal on historic responsibility (but this strongly depends on the parameter settings).

Rose et al. (1998) also compare several universal allocation regimes. They find the largest cost differences in the equal per capita allocation regime. In this regime, the costs for industrialized countries are especially high; this can be expected, since these countries currently have the highest per capita emissions. They also analyse an outcome-based allocation regime called horizontal equity, in which abatements costs are required to be an equal proportion of GDP for all. By definition, there are no cost differences between countries in such a regime.

The large cost differences for almost all allocation regimes are confirmed by other studies that analyse a single emission allocation regime (Blanchard 2002; Bollen et al. 2004; Böhringer and Löschel 2005; Wicke and Böhringer 2005 Böhringer and Welsch 2006; Persson et al. 2006; Rive et al. 2006; Vaillancourt and Waaub 2006; Peterson and Klepper 2007; Böhringer and Helm 2008). The large variation in the distribution of costs in almost every regime analysed will likely pose significant problems for full participation, even if average global costs are modest. At first glance, the horizontal equity allocation regime seems promising for achieving full participation, since in this regime every country incurs proportionally the same costs, figured as a share of GDP. Nevertheless, this regime is unlikely to achieve full participation, for two reasons. First, for many countries, especially developing ones, it might be unfair that they will have to pay the same costs as industrialized countries - even when calculated as a share of GDP. Second, in every universal regime the problem of free-riding remains (Carraro and Siniscalco 1998; Barrett 1999; Carraro 2000; Tol 2001; Dellink et al. 2005; Finus et al. 2005; 2006; Eyckmans and Finus 2007).

\section{Universal regimes without a global emission target}

We analyse cost projections for four universal regimes without a predefined global emission target (Table 4.2). 
Table 4.5 Abatement costs as per cent of GDP for nine regimes

\begin{tabular}{llllllllll}
\hline \hline Region & GC & CSE & AP & MS & C\&C & TT & BP & GF & MCC \\
\hline Canada & 3 & 3 & 3 & 3 & 3 & 2 & 2 & 2 & 2 \\
USA & 3 & 3 & 3 & 3 & 2 & 2 & 1 & 1 & 1 \\
OECD Europe & 2 & 2 & 2 & 2 & 2 & 2 & 2 & 2 & 1 \\
Eastern Europe & 3 & 2 & 1 & 1 & 1 & 2 & 1 & 1 & 1 \\
FSU & 3 & 3 & 1 & 3 & 3 & 3 & 3 & 2 & 2 \\
Oceania & 3 & 3 & 3 & 3 & 2 & 2 & 2 & 2 & 2 \\
Japan & 2 & 2 & 2 & 2 & 2 & 2 & 2 & 2 & 1 \\
Central America & 1 & 1 & 2 & 2 & 1 & 1 & 2 & 3 & 2 \\
South America & 2 & 2 & 2 & 2 & 2 & 1 & 2 & 3 & 2 \\
Northern Africa & 0 & 0 & 0 & 0 & 1 & 0 & 1 & 0 & 2 \\
Western Africa & 0 & 0 & 0 & 0 & 0 & 0 & 0 & 0 & 2 \\
Eastern Africa & 0 & 0 & 0 & 0 & 0 & 0 & 0 & 0 & 0 \\
Southern Africa & 2 & 1 & 0 & 0 & 3 & 1 & 0 & 0 & 3 \\
Middle East & 3 & 3 & 3 & 3 & 3 & 3 & 3 & 3 & 3 \\
South Asia & 0 & 0 & 0 & 0 & 0 & 0 & 0 & 0 & 1 \\
East Asia & 1 & 1 & 1 & 1 & 1 & 2 & 1 & 2 & 2 \\
South East Asia & 0 & 0 & 0 & 0 & 1 & 1 & 2 & 1 & 2 \\
\hline \hline
\end{tabular}

The table shows abatement costs as per cent of GDP in Purchasing Power Parity terms for nine regimes (all allowing for emission trading) in 2025 for greenhouse gas concentration stabilization at $550 \mathrm{ppm}$ carbon dioxide-equivalent.

Legend: $0=$ no costs or gains, $1=$ costs less than global average, $2=$ costs between global average and twice the global average, $3=$ costs more than twice the global average; GC: Global preference score compromise, CSE: Equal per capita allocation, AP: Ability to pay, MS: 'multistage' with differentiated reductions, C\&C: Contraction and convergence, TT: Triptych, BP: Historic responsibility: Brazilian proposal, GF: Grandfathering, MCC: Multi-criteria. Source: based on den Elzen and Lucas (2005).

\section{Dynamic targets: emissions intensity}

Blanchard (2002) analyses the economic consequences of a universal regime based on dynamic targets. This regime defines reduction targets as the ratio of carbon dioxide emissions to GDP. Although there is no global emission reduction target, Blanchard set the dynamic emission intensity targets at levels that stabilize carbon dioxide concentrations at 450 to $550 \mathrm{ppm}$. Emission intensity targets for industrialized countries are set at a reduction rate of approximately 2 per cent annually from business as usual, while developing countries have to improve their emissions intensity by 0.5 per cent annually. Due to these stricter targets for industrialized countries, the abatement costs in industrialized countries in 2030 are much higher than in developing countries. Abatement costs as share of GDP in industrialized countries range from twice the global average in the European Union to more than six times the global average in countries of the former Soviet Union. 


\section{Regimes based on cooperation}

Two other comparable universal regimes without a fixed global emission target are analysed by Buchner and Carraro (2003, 2004): Enhanced Global Cooperation and Technology Research and Development. Both regimes focus on cooperation between regions. In the Enhanced Global Cooperation regime, all countries cooperate in such a way that their joint welfare is maximized, and reduce emissions by an additional 10 per cent compared to this 'optimal path'. The Technology Research and Development regime focuses on global cooperation on technical innovation and diffusion, rather than maximization of joint welfare. Both of these regimes are sensitive to parameter settings like the discount rate and to uncertainties like the estimated damages of climate change, and might therefore be difficult to implement. With the parameters chosen in their study (which were deduced from the FEEMRICE model), costs are low for all regions, but the environmental effectiveness is also very low. The disadvantage of the Technology Research and Development regime is that - as a consequence of the intensified research and development efforts - production and therefore emissions increase. In other words, for a technology regime to be successful, a carbon-free direction of technology development must to be clearly specified (Alfsen et al., this volume, Chapter 13; Knopf and Edenhofer 2010).

\section{Global carbon emission tax}

Finally, the implementation of a global carbon emission tax is perhaps the most straightforward universal regime without a predefined emission target. Many studies have used a global carbon tax as a means to achieve emission reductions, but the regional results of such a regime have not regularly been reported. Table 4.6 summarizes the results of a global carbon emission tax from three studies, extended with our own calculations from the IMAGE framework and the ENV-Linkages model (see Section 4.2.1). ${ }^{3}$ The carbon tax in these studies was raised over time to reach a certain concentration stabilization level, with the exception of Bollen et al. (2005), who set the carbon emission tax at a constant $€ 20$ per tonne of carbon dioxide.

The various studies report similar results for most regions. All studies project that costs as share of GDP would be somewhat less than the global average for the European Union and the United States, and higher, or much higher, for the Middle East, the former Soviet Union, East Asia and Africa. Costs tend to be higher in developing countries because the burdens of a tax regime are carried mostly by those regions with high carbon intensity or with high opportunities to reduce emissions. In

\footnotetext{
3 Not included in the table are the results by Manne et al. (1995), who analysed a low carbon tax starting at USD 1 per tonne, increasing at 5 per cent per year. Results are reported for five regions only and are modest, as can be expected from such a low carbon tax.
} 
Table 4.6 Regional costs compared to global average costs (2)

\begin{tabular}{|c|c|c|c|c|c|c|c|c|}
\hline & USA & $\begin{array}{l}\text { European } \\
\text { Union/ } \\
\text { enlarged } \\
\text { European } \\
\text { Union }\end{array}$ & $\begin{array}{l}\text { FSU/ } \\
\text { Russia }\end{array}$ & $\begin{array}{l}\text { Middle } \\
\text { East// } \\
\text { Middle } \\
\text { East } \\
\text { and N } \\
\text { Africa }\end{array}$ & $\begin{array}{l}\text { Latin/ } \\
\text { South } \\
\text { America }\end{array}$ & $\begin{array}{l}\text { Africa/ } \\
\text { sub- } \\
\text { Saharan } \\
\text { Africa }\end{array}$ & $\begin{array}{l}\text { China/ } \\
\text { East } \\
\text { Asia }\end{array}$ & $\begin{array}{l}\text { India/ } \\
\text { South } \\
\text { Asia }\end{array}$ \\
\hline $\begin{array}{l}\text { Peterson and } \\
\text { Klepper } \\
(2007) \text { : } \\
\text { welfare } \\
\text { effects in } \\
2030\end{array}$ & 1 & 1 & 3 & 3 & 2 & 3 & 3 & 1 \\
\hline $\begin{array}{l}\text { Vaillancourt } \\
\text { et al. } \\
\text { (2008): } \\
\text { discounted } \\
\text { direct costs }\end{array}$ & 1 & 1 & 2 & 2 & 2 & 2 & 2 & 1 \\
\hline $\begin{array}{l}\text { Based on } \\
\text { IMAGE } \\
\text { framework: } \\
\text { direct costs } \\
\text { in } 2050\end{array}$ & 1 & 1 & 2 & 2 & 1 & 2 & 2 & 2 \\
\hline $\begin{array}{l}\text { Based on } \\
\text { ENV- } \\
\text { Linkages: } \\
\text { GDP loss in } \\
2050\end{array}$ & 1 & 1 & 3 & 2 & 1 & 1 & 2 & 3 \\
\hline $\begin{array}{l}\text { Bollen et al. } \\
\text { (2005): } \\
\text { income loss } \\
\text { in } 2020\end{array}$ & 1 & 1 & 3 & 3 & 2 & NA & NA & NA \\
\hline
\end{tabular}

The table shows regional costs compared to global average costs for a carbon emission tax of $€ 20$ per tonne (Bollen et al. 2005) and an increasing carbon emission tax in order to reach a greenhouse gas concentration stabilization level of $450 \mathrm{ppm}$ carbon dioxide-equivalent (IMAGE and ENV-Linkages) or $550 \mathrm{ppm}$ carbon dioxide-equivalent (other studies).

Legend: $1=$ costs less than global average, $2=$ costs between global average and twice the global average, $3=$ costs more than twice the global average; NA $=$ not available.

theory, a differentiated tax could equalize the cost burden among countries, although this would complicate the carbon tax implementation.

\subsubsection{Fragmented regimes}

Table 13.2 of the Working Group III contribution to the IPCC's Fourth Assessment Report (IPCC 2007: 770-773) mentions five fragmented regimes, 
Table 4.7 Economic consequences of fragmented climate regimes

\begin{tabular}{|c|c|c|}
\hline Name & Short description & Evaluated by \\
\hline European Union only & $\begin{array}{l}\text { Only European Union sets } \\
\text { emission targets }\end{array}$ & $\begin{array}{l}\text { Bollen et al. (2005), den Elzen } \\
\text { et al. (2007b), European } \\
\text { Commission (2007), Russ } \\
\text { et al. }(2005)\end{array}$ \\
\hline $\begin{array}{l}\text { Industrialized countries } \\
\text { technological } \\
\text { cooperation }\end{array}$ & $\begin{array}{l}\text { Replacement of international } \\
\text { cooperation on emission } \\
\text { reductions with international } \\
\text { cooperation between } \\
\text { industrialized countries on } \\
\text { technological innovation and } \\
\text { diffusion }\end{array}$ & Buchner and Carraro (2004) \\
\hline Developed minus US & $\begin{array}{l}\text { Developed countries except the } \\
\text { United States set emission } \\
\text { targets, rest of world does not }\end{array}$ & Böhringer and Löschel (2005) \\
\hline $\begin{array}{l}\text { Industrialized countries } \\
\text { only }\end{array}$ & $\begin{array}{l}\text { Only industrialized countries set } \\
\text { emission targets }\end{array}$ & $\begin{array}{l}\text { Bollen et al. (2005; 2005), } \\
\text { Böhringer and Löschel } \\
\text { (2005), Russ et al. }(2005)\end{array}$ \\
\hline $\begin{array}{l}\text { Industrialized countries } \\
\text { carbon tax }\end{array}$ & $\begin{array}{l}\text { Only industrialized countries } \\
\text { levy a carbon tax }\end{array}$ & Bollen et al. (2005) \\
\hline Without Asia and Africa & $\begin{array}{l}\text { Only developing Asian and } \\
\text { African countries do not set } \\
\text { emission targets }\end{array}$ & Bollen et al. (2005) \\
\hline Political willingness & $\begin{array}{l}\text { Regional emission constraints on } \\
\text { levels considered to be } \\
\text { politically acceptable } \\
\text { according to a number of } \\
\text { research institutes }\end{array}$ & den Elzen et al. (2007a) \\
\hline Fully fragmented & $\begin{array}{l}\text { A palette of internationally } \\
\text { fragmented climate policies }\end{array}$ & Boeters et al. (2007) \\
\hline
\end{tabular}

The table shows fragmented climate regimes that have been analysed regarding their economic consequences, from low to high participation.

which are rather generally defined. Most quantitative studies on fragmented regimes make assumptions about the level of participation: only one climate regime is adopted, but not all countries participate in this regime. The participating countries adopt reduction targets based on expert judgements about what they might be willing to do, or reduction targets would be set at such levels in order to reach a global emission target. Only two studies analyse the costs of fragmented regimes with several different climate agreements (Boeters et al. 2007; den Elzen et al. 2007a). We will discuss a range of fragmented regimes from low to high participation (see Table 4.7). 


\section{Emission targets for the European Union only}

The regime with the lowest participation analysed is one in which only the European Union sets emission targets. According to this analysis, if the European Union were to set a target of 20 per cent emission reduction in 2020 or 2025 (compared to 1990), and joint implementation and the clean development mechanism are available, abatement costs and welfare losses for the European Union would be very small less than 0.3 per cent in 2020 (Russ et al. 2005; den Elzen et al. 2007b; European Commission 2007, 2008). Two studies look at the implications of a 30 per cent reduction target for the European Union only. Bollen et al. (2005) estimates income losses for the European Union of such a target of 2 per cent in 2020; a study by the European Commission (2007) finds GDP losses of 0.9 per cent in 2025. Even with the more stringent target of a 30 per cent emission reduction, the effectiveness of such a regime on a global scale is very low: by 2020, the global emission reduction would be less than 5 per cent compared to the no-climate policy case.

\section{Technological cooperation between industrialized countries}

This fragmented regime is slightly different than the rest as the focus is not on emission reduction targets, but on technological cooperation between industrialized countries. The advantage of such a coalition is that the consequences can be relatively easily assessed by decision-makers. Buchner and Carraro (2004) assess this regime with the same assumptions as in their Enhanced Global Cooperation regime (see Section 4.1.2). The results are similar: environmental effectiveness is very low, because global emissions and even the emission/output ratio increase in this regime. This is the result of production increases due to intensified research and development efforts (as in the universal Technology Research and Development regime). Emissions per unit of output also increase, because the overall impact of accumulated research and development expenditure on economic growth is larger than the impact of accumulated research and development on emission abatement.

\section{Emission targets for industrialized countries only}

Böhringer and Löschel (2005) analyse the possibility of all industrialized countries except the United States setting emission targets. Although the United States and developing countries do not set emission targets, the study assumes that these regions can sell project-based emission reductions to the reducing countries (leading to mutual benefits). The global emission reduction target is set at 10 per cent below baseline in 2020. Different allocation rules are used to allocate this global reduction to Australia and New Zealand, Canada, the European Union, the former Soviet Union and Japan. The sovereignty rule (also called grandfathering, that is, reduction

EBSCO Publishing : eBook Collection (EBSCOhost) - printed on 10/31/2019 5:07 AM via UTRECHT UNIVERSITY AN: 416647 ; Biermann, Frank, Pattberg, Philipp H., Zelli, Fariborz.; Global Climate Governance Beyond 2012 : Architecture, Agency and Adaptation Account: s4754244.main. ehost 
obligations based on current emissions) and the polluter-pays principle (that is, reduction obligations based on past emissions) lead to emission reductions of 30-38 per cent compared to baseline in 2020 in each of the regions. The allocation rule ability-to-pay (that is, reduction obligations based on welfare), on the other hand, leads to an emission reduction target for the former Soviet Union by only 5 per cent, whereas Japan has to reduce emissions by 66 per cent. Figure 4.2a summarizes the abatement costs (measured in consumption loss).

A fragmented climate regime in which all industrialized countries participate (thus including the United States) leads to similar results. The results of Böhringer and Löschel (2005) are shown in Figure 4.2b. The participation of the United States leads to small reductions of costs for other industrialized countries. Bollen et al. (2005) analyse a similar regime, but with a more stringent target and allocation based on per capita emission convergence in 2024. Consistent with the results of Böhringer and Löschel, this leads to high costs for the former Soviet Union. In contrast with that study, however, they conclude that there are benefits for the Middle East and that the European Union and United States will incur higher costs. The latter can be explained by the more stringent target and the early convergence year (which is less beneficial for industrialized countries, see Section 4.3.1). Their main conclusion is that switching from a global coalition (universal regime) to a smaller coalition of industrialized countries (fragmented regime) more than doubles the cost of the European Union objective of $2^{\circ} \mathrm{C}$, even with the possibility of the clean development mechanism in its current form. With such a regime, developing countries (except energy exporting countries) would benefit and thus effectively become free-riders. This might create an obstacle for establishing a coalition in which only industrialized countries participate.

\section{Carbon emission tax for industrialized countries only}

Besides setting emission targets, industrialized countries also could levy a carbon tax. Like the universal Global Carbon Emission Tax, Bollen et al. (2005) analyse the carbon tax for industrialized countries with a tax of $€ 10$ and $€ 20$ per tonne carbon dioxide. Whereas a global carbon tax of $€ 20$ per tonne carbon dioxide would reduce emissions by 25 per cent compared to baseline, a carbon tax limited to industrialized countries would reduce emissions only by 10 per cent. The costs are distributed differently as well; as expected, industrialized countries (especially the former Soviet Union) carry the burden in this regime.

\section{Emission targets for all countries except developing countries in Africa and Asia}

Bollen et al. (2004) analyse a fragmented regime in which only developing African and Asian countries refuse to join a climate coalition. They assume that the rest of 
(a)

(a) Developing countries Industrialized countries

World

Middle and South America

Mexico and OPEC

India

China

Asia

Africa

USA

Japan

Former Soviet Union

Europe

Oceania

(b)

Developing countries
Industrialized countries

World

Middle and South America

Mexico and OPEC

India

China

Asia

Africa

USA

Japan

Former Soviet Union

Europe

Canada

Oceania

$$
-2.0 \%
$$

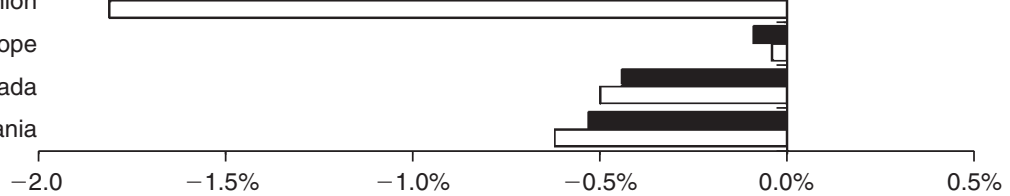

Ability to pay $\square$ Sovereignty

Figure 4.2 Change in consumption in 2020 relative to business-as-usual. This analysis applies in a regime where only industrialized countries set emission targets, allocated based on the sovereignty rule or ability to pay, so that global emissions are reduced by 10 per cent compared to business as usual. (a) Coalition without the United States; (b) coalition with the United States. Source: based on Böhringer and Löschel (2005).

the world sets an emission target of 30 per cent below 1990, allocated according to 'contraction and convergence'. The EU objective could be reached with such a regime, but the global income loss in 2020 would be almost three times higher compared to a universal 'contraction and convergence' regime. 


\section{Political willingness scenario}

The Political willingness scenario, an outcome of the South-North dialogue, is an example of a fragmented regime with large participation (den Elzen et al. 2007a). In this proposal, emission reduction targets for different regions are set at levels based on an assessment by a number of research institutes involved in the SouthNorth dialogue proposal. This scenario neither establishes a global emission target, nor requires regions to base their emission reduction targets on a universal regime. This proposal resembles the fragmented bottom-up or multifaceted approach, in which each country creates its own initial proposal relating to what it might be able to commit to (Reinstein 2004). According to the proposal, the European Union reduces emissions by 30 per cent in 2020 as compared to 1990; other industrialized countries by 15 per cent; newly industrialized countries by 30 per cent; and rapidly industrializing countries by 10 per cent. Developing countries continue their baseline emissions until 2020. It is implicitly assumed that all regions will comply because of political will. The costs of the political willingness scenario as a share of GDP would be similar among industrialized countries, while most developing countries would gain from financial transfers from emission trading. With the global emission reduction by 2020 resulting from this scenario, the stabilization at a concentration of 500 ppm carbon dioxide-equivalent is kept just within reach.

\section{A fully fragmented regime compared with a universal regime}

Boeters et al. (2007) analyses yet another fragmented regime. In contrast to the previous regimes, here even the type of goals varies by region. The United States, Australia and Canada would focus on technology improvement, while the European Union and Japan would continue with emission targets combined with emissions trading. Fast-developing countries would not set emission targets, but would invest mainly in local air quality. For a more detailed description of this fragmented regime, see Boeters et al. (2007). Table 4.8 compares this fragmented regime with a universal 'multi-stage' regime, also analysed in the same study.

As the table shows, the global costs of the universal 'multi-stage' regime and the fragmented regime are the same, even though the 'multi-stage' regime achieves much higher emission reductions. Another important conclusion is that no country involved in the 'multi-stage' regime is worse off as compared to the proposed fragmented regime, with the notable exception of the United States. In other words, there might be an incentive for the United States not to join a universal regime (however, allocation rules other than the ones of the 'multi-stage' proposal can limit the costs for the United States; see Table 4.5). 
Table 4.8 Comparison of a fully fragmented regime with a universal regime

\begin{tabular}{|c|c|c|c|c|c|c|}
\hline & \multicolumn{2}{|c|}{ Target $(2020$, relative to 1990$)$} & \multicolumn{2}{|c|}{$\begin{array}{l}\text { Emission price }(€ / \text { tonne } \\
\text { carbon dioxide })\end{array}$} & \multicolumn{2}{|c|}{ Change in national income (by 2020) } \\
\hline & Universal & Fragmented & Universal & Fragmented & Universal & Fragmented \\
\hline Industrialized countries & -20 per cent & -1 per cent & 24 & 25 & -0.3 per cent & -0.3 per cent \\
\hline European Union-25 & -23 per cent & -15 per cent & 24 & 51 & -0.4 per cent & -0.6 per cent \\
\hline USA & -24 per cent & +25 per cent & 24 & 14 & -0.3 per cent & -0.0 per cent \\
\hline FSU & -13 per cent & -25 per cent & 24 & 7 & +0.8 per cent & -0.7 per cent \\
\hline Rest OECD & -16 per cent & +3 per cent & 24 & 34 & -0.4 per cent & -0.4 per cent \\
\hline Non-Annex I & +100 per cent & +147 per cent & - & - & 0.0 per cent & 0.0 per cent \\
\hline China & +101 per cent & +105 per cent & 24 & 2 & +0.4 per cent & 0.0 per cent \\
\hline India & +210 per cent & +203 per cent & 24 & 4 & +0.1 per cent & 0.0 per cent \\
\hline World & +28 per cent & +45 per cent & - & - & -0.2 per cent & -0.2 per cent \\
\hline
\end{tabular}

The table shows targets, emission prices and national income changes for a fully fragmented regime compared to a universal regime based on a multi-stage emission allocation rule.

Source: Boeters et al. (2007). 


\subsection{Conclusions and policy recommendations}

This chapter reviewed several quantitative studies about the costs and environmental effectiveness of different universal and fragmented regimes. A large number of studies exist that qualitatively discuss different climate regimes or discuss only the emission reductions resulting from these regimes. The number of studies also discussing regional economic consequences is much more limited. In the studies that do provide costs analyses, different tools are used, such as macroeconomic models. We find that, in general, studies agree on what regions will experience high, medium or low costs under different regimes, even when using different tools.

The chief conclusions from the review of universal regimes are that (1) theoretically, binding universal regimes with high emission reduction targets or a carbon tax can achieve ambitious reduction targets at relatively low costs; and (2) almost all examined allocation regimes result in significant cost differences (in terms of costs as share of GDP) between regions. The last conclusion is obviously a major challenge for forming international coalitions. There is no single formula for emission allocation that satisfies all possible country conditions, as there is a generic conflict between a simple transparent formula and incorporating many national circumstances. As an example, both energy system and general equilibrium models indicate that Africa and South Asia would benefit from a universal climate regime based on 'contraction and convergence' with 2050 as the convergence year, while the former Soviet Union and Middle East are projected to incur high costs. In that context, for any real-world agreements, the outcomes of specific allocation rules will at best serve as a starting point for negotiations. The cost differences could be smaller after a negotiation process, which would increase the likelihood of accepting such a proposal.

From the studies that have analysed fragmented regimes, we learn that in general, it is more cost-effective to reduce emissions in a universal regime than in a fragmented regime. One reason is that with lower participation, it is more difficult for the participating regions to reach a certain global emission target (they need to compensate the higher emissions of the non-participating regions). In addition, even with high participation fragmentation implies that emission reductions are not made where it is cheapest to do so (no emission trading is usually possible between regions participating in different agreements). However, despite the higher overall costs, a fragmented regime consisting of multiple agreements could be more feasible to attain. This is mainly because individual countries have an incentive to free-ride on a universal regime.

There are many criteria to assess climate regimes. The current study mainly focused on environmental effectiveness and cost efficiency (and for instance not 
on institutional feasibility). Based on the long-term advantages of universal regimes for these criteria, but also the difficulties in establishing such regimes, one may argue that some kind of transition from a fragmented regime to a universal regime could provide the best possibility to achieve strong emission reductions. To simplify negotiations, a transitional, ambitious, fragmented regime consisting of all major emitting countries could be established in the short term. Such a coalition could provide the basis for a larger, universal regime in the long term. Transfer schemes or other interlinkages (Flachsland et al., this volume, Chapter 5; and Zelli and van Asselt, this volume, Chapter 6) might help to achieve such a universal regime.

In terms of the mapping criteria applied in this volume, the political dimension of this recommendation is purely policy-based, since the institutional settings and type of actors involved were not subject of our analysis. This means that we do not have concrete recommendations about the international institutional environment, the type of actors involved in decision-making and the mode of governance applied to implement the policy suggestions. This notwithstanding, our recommendation of transitional fragmented regime could be interpreted as a cross-institutional solution which involves the UN climate regime along with several other institutions.

\section{References}

Bakkes, J. and P. Bosch (eds.) 2008. Background Report to the OECD Environmental Outlook to 2030. Bilthoven: Netherlands Environmental Assessment Agency, and Paris: Organization for Economic Co-operation and Development.

Barrett, S. 1999. 'A theory of full international cooperation', Journal of Theoretical Politics 11: $519-541$.

Bell, W., J. van Ham, J.-E. Parry, J. Drexhage and P. Dickey 2005. Canada in a Post-2012 World: A Qualitative Assessment of Domestic and International Perspectives. Winnipeg: International Institute for Sustainable Development.

Berk, M. M. and M. G. J. den Elzen 2001. 'Options for differentiation of future commitments in climate policy: how to realise timely participation to meet stringent climate goals?', Climate Policy 1: 465-480.

Blanchard, O. 2002. 'Scenarios for differentiating commitments', in K. A. Baumert (ed.), Building on the Kyoto Protocol: Options for Protecting the Climate. Washington, DC: World Resources Institute, pp. 203-222.

Blok, K., N. Höhne, A. Torvanger and R. Janzic 2005. Towards a Post-2012 Climate Change Regime. Brussels: 3E.

Bodansky, D. 2004. International Climate Efforts beyond 2012: A Survey of Approaches. Arlington, VA: Pew Center on Global Climate Change.

Boeters, S., M. G. J. den Elzen, T. Manders, P. Veenendaal and G. Verweij 2007. Post-2012 Climate Policy Scenarios. Bilthoven: Netherlands Environmental Assessment Agency.

Böhringer, C. and C. Helm 2008. 'On the fair division of greenhouse gas abatement cost', Resource and Energy Economics 30: 260-276.

Böhringer, C. and A. Löschel 2005. 'Climate policy beyond Kyoto: quo vadis? A computable general equilibrium analysis based on expert judgments', Kyklos $\mathbf{2 8}$ : 467-493. 
Böhringer, C. and H. Welsch 2004. 'Contraction and convergence of carbon emissions: an intertemporal multi-region CGE analysis', Journal of Policy Modeling 26: 21-39.

Böhringer, C. and H. Welsch 2006. 'Burden sharing in a greenhouse: egalitarianism and sovereignty reconciled', Applied Economics 38: 981-996.

Bollen, J., T. Manders and P. Veenendaal 2004. How Much Does a 30 Per Cent Emission Reduction Cost? Macroeconomic Effects of Post-Kyoto Climate Policy in 2020. The Hague: Netherlands Bureau for Economic Policy Analysis.

Bollen, J., T. Manders and P. Veenendaal 2005. Caps and Fences in Climate Change Policies: Trade-Offs in Shaping Post-Kyoto. Bilthoven: Netherlands Environmental Assessment Agency.

Buchner, B. and C. Carraro 2003. 'Future commitments and participation incentives: some climate policy scenarios', paper presented at the Berlin Meeting of the Second ESRI (Economic and Social Research Institute of the Government of Japan) Collaboration Project on Environmental Issues, Berlin, 15-16 October 2003.

Buchner, B. and C. Carraro 2004. Economic and Environmental Effectiveness of a Technology-Based Climate Protocol, Working Paper No. 61.04. Milan: FEEM (Fondazione Eni Enrico Mattei).

Carraro, C. 2000. 'The economics of coalition formation', in J. Gupta and M. Grubb (eds.), Climate Change and European Leadership: A Sustainable Role for Europe? Dordrecht: Kluwer Academic Publishers, pp. 135-156.

Carraro, C. and D. Siniscalco 1998. 'International environmental agreements: incentives and political economy', European Economic Review 42: 561-572.

Criqui, P., A. Kitous, M. Berk, M. G. J. den Elzen, B. Eickhout, P. Lucas, D. P. van Vuuren, N. Kouvaritakis and D. Vanregemorter 2003. Greenhouse gas Reduction Pathways in the UNFCCC Process up to 2025, Technical Report B4-3040/2001/325703/MARE/ E.1. Grenoble: DG Environment.

Dellink, R., M. Finus and N. Olieman 2005. Coalition Formation under Uncertainty: The Stability Likelihood of an International Climate Agreement, Working Paper No. 98.2005. Milan: FEEM (Fondazione Eni Enrico Mattei).

den Elzen, M. G. J. and P. Lucas 2005. 'The FAIR model: a tool to analyse environmental and costs implications of climate regimes', Environmental Modeling and Assessment 10: $115-134$.

den Elzen, M. G. J., M. Berk, P. Lucas, B. Eickhout and D. P. van Vuuren 2003. Exploring Climate Regimes for Differentiation of Commitments to Achieve the EU Climate Target. Bilthoven: Netherlands Environmental Assessment Agency.

den Elzen, M. G. J., N. Höhne, B. Brouns, H. Winkler and H. E. Ott 2007a. 'Differentiation of countries' future commitments in a post-2012 climate regime: an assessment of the "South-North Dialogue" proposal', Environmental Science and Policy 10: $185-203$.

den Elzen, M. G. J., P. Lucas and A. Gijsen 2007b. Exploring European Countries' Emission Reduction Targets, Abatement Costs and Measures Needed under the New EU Reduction Objectives. Bilthoven: Netherlands Environmental Assessment Agency.

den Elzen, M. G. J., P. Lucas and D. P. van Vuuren 2005. 'Abatement costs of post-Kyoto climate regimes', Energy Policy 33: 2138-2151.

den Elzen, M. G. J., P. Lucas and D. P. van Vuuren 2008. 'Regional abatement action and costs under allocation schemes for emission allowances for achieving low $\mathrm{CO}_{2}$-equivalent concentrations', Climate Change 90: 243-268.

European Commission 2007. Limiting Global Climate Change to $2^{\circ}$ Celsius: The Way Ahead for 2020 and Beyond. Brussels: European Council.

EBSCO Publishing : eBook Collection (EBSCOhost) - printed on 10/31/2019 5:07 AM via UTRECHT UNIVERSITY AN: 416647 ; Biermann, Frank, Pattberg, Philipp H., Zelli, Fariborz.; Global Climate Governance Beyond 2012 : Architecture, Agency and Adaptation 
Eyckmans, J. and M. Finus 2007. 'Measures to enhance the success of global climate treaties', International Environmental Agreements: Politics, Law and Economics 7: 73-97.

Finus, M., J.-C. Altamirano-Cabrera and E. C. van Ierland 2005. 'The effect of membership rules and voting schemes on the success of international climate agreements', Public Choice 125: 95-127.

Finus, M., E. C. van Ierland and R. Dellink 2006. 'Stability of climate coalitions in a cartel formation game', Economics of Governance 7: 271-291.

Gupta, J. 1998. Encouraging Developing Country Participation in the Climate Change Regime, Discussion Paper E98-08. Amsterdam: Vrije Universiteit, Institute for Environmental Studies.

Höhne, N., C. Galleguillos, K. Blok, J. Harnisch and D. Phylipsen 2003. Evolution of Commitments under the UNFCCC: Involving Newly Industrialized Economies and Developing Countries. Cologne: Ecofys.

IPCC 2007. Climate Change 2007: Mitigation of Climate Change. Contribution of Working Group III to the Fourth Assessment Report of the Intergovernmental Panel on Climate Change. Geneva: IPCC.

Knopf, B. and O. Edenhofer 2010 (in press). 'The economics of low stabilisation: implications for technological change and policy', in M. Hulme and H. Neufeldt (eds.), Making Climate Change Work for Us: European Perspectives on Adaptation and Mitigation Strategies. Cambridge, UK: Cambridge University Press.

Leimbach, M. 2003. 'Equity and carbon emissions trading: a model analysis', Energy Policy 31: 1033-1044.

Manne, A. and R. Richels 1995. 'The greenhouse debate: economic efficiency, burden sharing and hedging strategies', Energy Journal 16: 1-37.

Manne, A., R. Mendelsohn and R. Richels 1995. 'MERGE: a model for evaluating regional and global effects of GHG reduction policies', Energy Policy 23: 17-34.

Nakicenovic, N. and K. Riahi 2003. Model Runs with MESSAGE in the Context of the Further Development of the Kyoto Protocol. Berlin: German Advisory Council on Global Change.

Persson, T. A., C. Azar and K. Lindgren 2006. 'Allocation of CO2 emission permits: economic incentives for emission reductions in developing countries', Energy Policy 34: $1889-1899$.

Peterson, S. and G. Klepper 2007. Distribution Matters: Taxes vs. Emissions Trading in Post Kyoto Climate Regimes, Working Paper No. 1380. Kiel: Institute for World Economics.

Philibert, C. 2005. Approaches for Future International Co-operation. Paris: Organization for Economic Co-operation and Development, and International Energy Agency.

Reinstein, R. A. 2004. ' A possible way forward on climate change', Mitigation and Adaptation Strategies for Global Change 9: 245-309.

Rive, N., A. Torvanger and J. S. Fuglestvedt 2006. 'Climate agreements based on responsibility for global warming: periodic updating, policy choices, and regional costs', Global Environmental Change 16: 182-194.

Rose, A., B. Stevens, J. Edmonds and M. Wise 1998. 'International equity and differentiation in global warming policy: an application to tradeable emission permits', Environmental and Resource Economics 12: 25-51.

Russ, P., J. C. Ciscar and L. Szabo 2005. Analysis of Post-2012 Climate Policy Scenarios with Limited Participation. Brussels: European Commission, Joint Research Centre and Institute for Prospective Technological Studies.

EBSCO Publishing : eBook Collection (EBSCOhost) - printed on 10/31/2019 5:07 AM via UTRECHT UNIVERSITY AN: 416647 ; Biermann, Frank, Pattberg, Philipp H., Zelli, Fariborz.; Global Climate Governance Beyond 2012 : Architecture, Agency and Adaptation 
Tol, R. S. J. 2001. 'Climate coalitions in an integrated assessment model', Computational Economics 18: 159-172.

Vaillancourt, K. and J.-P. Waaub 2006. 'A decision aid tool for equity issues analysis in emission permit allocations', Climate Policy 5: 487-501.

Vaillancourt, K., R. Loulou and A. Kanudia 2008. 'The role of abatement costs in GHG permit allocations: a global stabilization scenario analysis', Environmental Modeling and Assessment 13: 169-179.

van Vuuren, D. P., M. G. J. den Elzen, P. L. Lucas, B. Eickhout, B. J. Strengers, B. van Ruijven, S. Wonink and R. van Houdt 2007. 'Stabilizing greenhouse gas concentrations at low levels: an assessment of reduction strategies and costs', Climatic Change 81: 119-159.

Wicke, L. and C. Böhringer 2005. Cost Impacts of a 'Beyond Kyoto' Global Cap and Trade Scheme. Berlin: Institut für Umweltmanagement. 